\title{
締切堤の建設が河口部や沿岸域の干潟 に及ぼす影響の予測 PREDICTION OF INFLUENCES ON THE TIDAL FLAT BY AN ENCLOSURE OF BAY
}

\author{
西田渉 1 ・野口正人 2 ・柳本諭 3 \\ Wataru NISHIDA, Masato NOGUCHI and Satoshi YANAMOTO \\ 1正会員 工修 長崎大学助手 工学部社会開発工学科（广852-8521長崎県長崎市文教町1-14） \\ $2 フ ェ ロ ー$ 工博 長崎大学教授 工学部社会開発工学科 (同上)

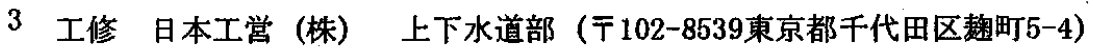

\begin{abstract}
As the construction of sea dyke has come to finish on April 14, 1997, the $35.5 \mathrm{~km}^{2}$ area of original Isahaya Bay has been separated from sea, and will be changed to land in near future. It is considered that the spatial distribution of tidal flat around the Isahaya Bay is severely affected by the progress of reclamation project. Thus, numerical simulations were carried out in order to examine and evaluate the influences by an enclosure of bay. Calculated results show that the shoreline in the Isahaya Bay varies as the decrease of water exchange between inside and outside of the sea dyke. Moreover, because of the decreased velocity of current, deposition is occurred in front of the dyke. These results imply that the possibility of an appearance of tidal flat, and its area is influenced by the control of gates. It consequently indicates that adequate attention should be paid to preserve and create the tidal flat.
\end{abstract}

Key Words : Sea dyke, tidal flat, influence analysis, numerical simulation

\section{1. 序論}

現在，長崎県の東部に位置する諫早湾では，防災 機能の強化と農地の造成とを主な目的とした諫早湾 干拓事業が進められているが (図一1)，平成 9 年 4 月14日に実施された潮止め工事によって, 湾奥部 の約3,550haが締め切られた。 そのため, 諫早湾を はじめとする水域では，流れや物翼の流送過程等が 大きく変化し, 当水域の水環境は, 今後, 急速に変 わるものと予想される.こうした大規模事業の水域 一の影響については, 物理学的, 化学的, 生物学的 諸側面から十分な検討がなされなければならないが， 関係行政機関においては，定期的なモニタリングを とおして環境への影響把握に努めている。著者らも， 現地観測, 並びに数值シミュレーション等をとおし て, 干拓事業が, 諫早湾の流れや水質変化機構に与 える影響の評価を試みてきた. ${ }^{1-2)}$

ところで, 諫早湾は, 干満差の大きい禹原湾の一 部であることから，湾の沿岸部では干潮時に広大な 干潟が現れる. 諫早湾の干潟は, 前浜干潟に分類さ れており ${ }^{3)}$ ，底質は非常に軟弱なシルト・粘土質の 微細な土粒子で構成されている，通常，干潟につい
ては, 多種・多様な生物の生息地であり, 生態学的 に重要な場所であると同時に, 水質の浄化に対して も大きく貢献しているものと考えられている4).こ こで, 後者について考えれば, 干拓事業の進展に伴 う諫早湾の干潟の変化は, 湾内の水質変化機構に少 なからず影響を及ぼすものと推察される。

以上のことから, 本研究では, 干潟の空間分布の 変化を明らかにすることは, 将来, 諫早湾やその周 辺水域での水環境管理を適切に進めていくうえで大

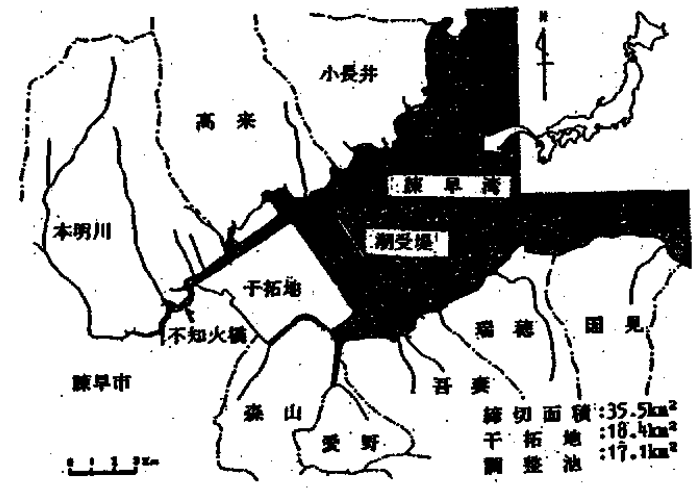

图一 1 諫早湾干拓事業の概要図 
切な因子の一つであると考え，締切堤の建設による 干潟の空間分布の変化について，数值モデルを用い て予測，評価与ることにした。

\section{2. 数值予測モデル}

ここで, 干潟を潮汐の変化に伴って, 満潮時に海 面下に没し, 干潮時に再び海面上に露出する領域と すると，締切堤の建設によって，海水の諫早湾への 流入量が抑えられることで汀線が変化し，干潟の面 積仙変化与るもの上思われる。また，湾内の流送士 砂量の変化によっては，干潟が，新たに発達，もし く泣，消滅することも予想される，そこで，諫早湾 の底質が微細な土粒子で構成されていることを考慮 して，底質の堆積厚さは，土粒子の巻き上げ，堆積 の効果によって変化するものとして, 現象のモデル 化がなされた ${ }^{2)}$.なお，巻き上げられた土粒子は， 浮遊状態で流送されるものと仮定された。計算に用 いた基礎方程式は，流れの連続方程式，運動方程式, 浮流砂の収支式である。ただし，底泥粒子の水底か らの巻き上げ量は, Pick-up rate ${ }^{5)}$ で表現されるも の上した。 また，底泥粒子の巻き上げについては， 底泥の粘着性を考慮して, 堆積厚さが薄くなるに 従って底泥粒子が巻き上げられにくくなるものと仮 定した。 以下に計算で用いられた巻き上げフラック ス $F C$ の評価式, 沈降フラックス $F d の$ 評価式を示す.

$$
\begin{aligned}
& F_{C}=\left\{\begin{array}{lr}
0 & \cdots \cdots \cdots \cdot \tau_{*} \leq \tau_{*_{c}} \\
\sigma \cdot V_{s} \cdot P_{s} \cdot P_{l} / a_{s} \cdots \cdots \cdots \cdot \tau_{*} \geq \tau_{*_{c}}
\end{array}\right. \\
& F_{d}=C_{b} \cdot w_{0} \cdot \exp \left(-v^{2} / v_{c}^{2}\right) \\
& P_{l}=\exp \left\{-\gamma\left(1-D / D_{i n i}\right)\right\}
\end{aligned}
$$

ここに, $\tau_{* f}$ : 無次元掃流力, $\tau_{* f c}$ : 土粒子の移動 限界時の無次元掃流力, $\sigma$ : 上粒子の密度, $V_{s}$ : 土 粒子の体積, $P_{s}$ : 底泥粒子のPick-up rate, $P_{1}$ : 底 泥の巻き上げられやすさに関する係数， $a_{s}$ : 土粒子 の断面積, $C b$ : 河床近傍での浮流砂の濃度, $w_{0}$ : 沈 降速度, $v$ : 流速, $v c$ : 浮遊粒子の重量と流体力の 釣り合い式から算出された浮遊限界流速, $D$ : 底泥 粒子の堆積厚さ, Dini : 底泥粒子の初期堆積厚さ,

である。

数值モデルを作成寸るにあたって，河口域では河 川と海域との浮流砂の収支を考慮する必要があるこ と, これまでの計算結果から, 締切堤の建設の流れ に及ぼす影響は, 諫早湾の湾口部にまで及ぶことが 予想されたこと等，の理由から，図一2に示される 領域が計算対象とされた。 そのため, 基礎方程式は, 河道と海域に対して，それぞれ 1 次元解析法, 2 次 元解析法が適用された. 各コントロールボリューム で体積積分された基礎方程式は, 陽形式のドナーセ ル法を適用して離散化された. 空間差分間隔は, 1 次元解析領域に対して $\delta s=52.0 \sim 147.0 \mathrm{~m}$ とされ,

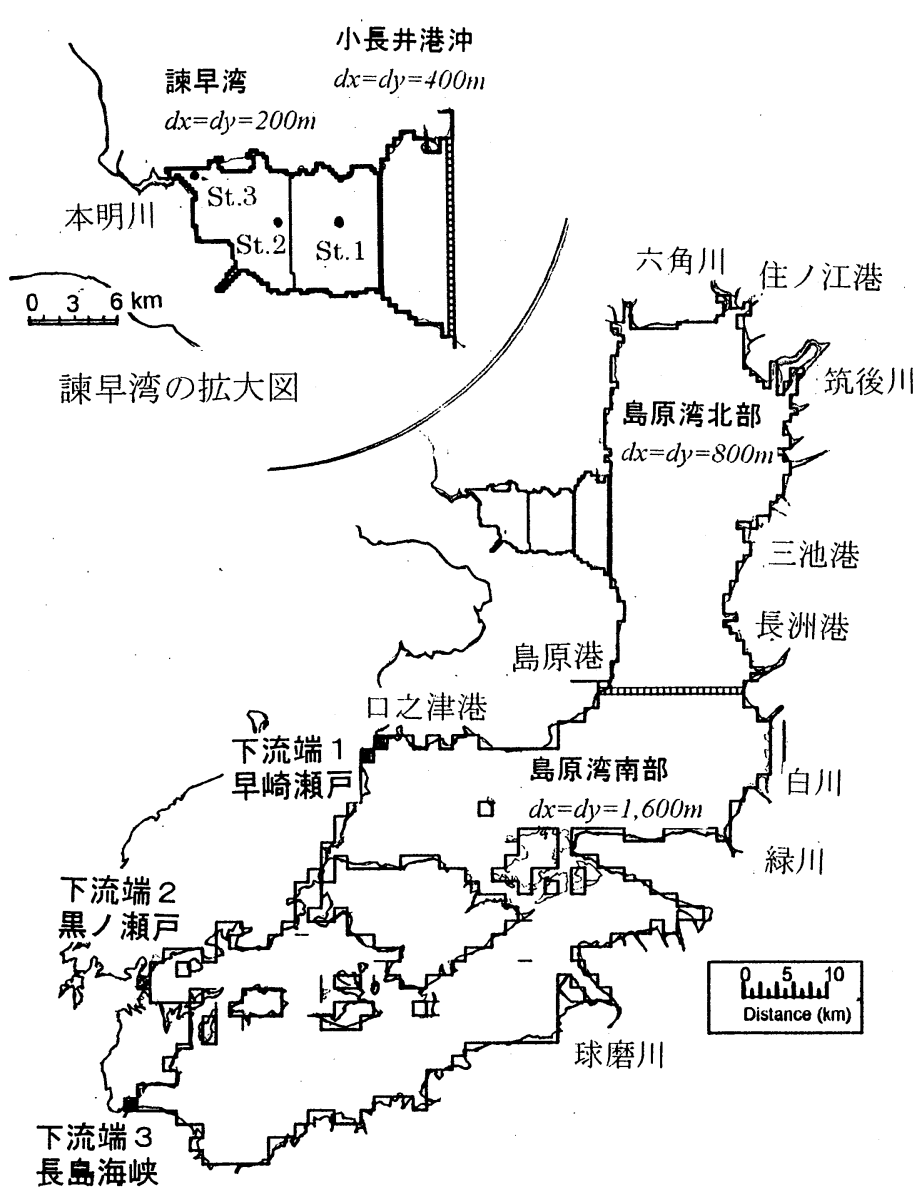

図-2 計算対象領域と各計算領域の接続格子 (図には，汀線も記されている)

2 次元解析領域に対して, 同時型の粗細格子法を適 用することとし，200，400，800，1600யの格子で図 -2のように覆った。 なお，各格子で算出された物 理量の受け渡しについては，狭格子領域の計算値か ら, 広格子領域の接続点の各物理量が算出されるも のとした。時間差分間隔は, 計算の安定条件である C. F. L 条件と土粒子の水底からの離脱の時間スケー ルを考慮して，1.0secとされた。

境界条件については，本明川とその支川（福田川, 半造川）の上流端で現地観測の結果をもとに流量 $0.909 \mathrm{~m}^{3} / \mathrm{sec}, 0.474 \mathrm{~m}^{3} / \mathrm{sec}, 0.060 \mathrm{~m}^{3} / \mathrm{sec}$, また

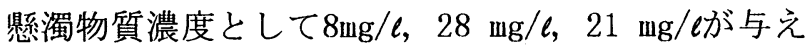
られた。流端境界である早崎瀬戸，黒の瀬戸，長 島海峡では，M2分潮に相当する正弦波を水位変化を 与えることとし, 各地点での振幅は参考文献 $2.00 \mathrm{~m}, 1.62 \mathrm{~m}, 1.63 \mathrm{~m}$ とれた. 水底の土粒子は球 体として取り扱われ，その粒径は諫早湾における代 表粒径 $50.0 \mu \mathrm{m}$ ，比重 2.60 とされた。河道と海域で の初期堆積厚さは空間的に変化するものであり，そ の詳細な把握は極めて困難である。ここでは初期堆 積厚さを全計算領域で一様に与えて計算を行い，そ の後, 流れと底質の移動が安定した時の堆積量を初 期量とした。ここに, 計算開始時の堆積厚さは, 諫 早湾湾奥部での懸濁物質の時間変化の観測結果と計 算結果との比較から，河道と海域でそれぞれ0.03 m, 


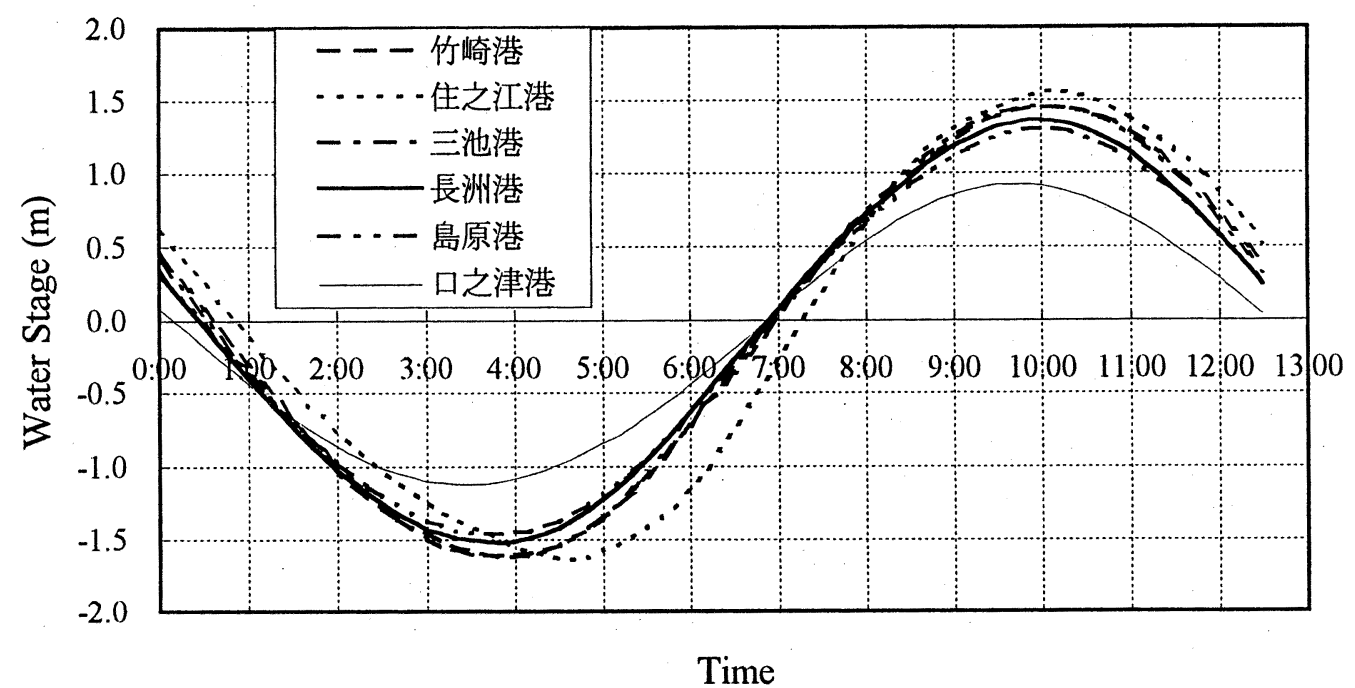

図一３島原湾における水位の時間変化

$0.01 \mathrm{~m}$ とした，助走計算については，比較的広い領 域を対象之寸るにも拘わらず，流れは，計算開始後， 約37時間で安定した結果となる。一方，底質の移動 注74時間以上を要することから，以下の計算では， 助走計算を124時間分だけ行うこととした。

\section{3. 計算結果と考察}

\section{(1) 数値モデルの妥当性の検討}

干潟の変化予測の計算を行うにあたり，まず，モ デルの流れの再現性の検討を行った. 図ーろには, 島原湾の代表的な港湾における水位の時間変化が示 されている。これらの計算結果は, 海域のManning の粗度係数を $\mathrm{n}=0.028 \mathrm{sec} / \mathrm{m}^{1 / 3}$ とした時のものである.

島原湾の潮位差は, 口之津港から島原湾の湾奥八 近づくにつれて, 次第に大きくなっており, 最高・ 最低水位となる時刻は, 口之津港よりも遅れること が分かる. 住ノ江港での干満差は，口之津港のそれ の約1.6倍に達しており, また, 水位の時間変化は, 他の港湾に比心゙て，上げ潮時には速く上昇し，下げ 潮時には緩やかに下降するようである。こうした水 位変化になるのは，上げ潮時には，六角川の河口

表 -1 潮時差と干满差の文献值との比較

\begin{tabular}{ccccccc}
\hline & & 島原港 & 三池港 & 長洲港 & 竹崎港 & 住之江港 \\
\hline \hline 干満差 & 計算 & 1.38 & 1.53 & 1.44 & 1.53 & 1.60 \\
(III) & 文献 & 1.47 & 1.53 & 1.43 & 1.53 & 1.72 \\
\hline 潮時差 & 計算 & 20 & 20 & 15 & 25 & 30 \\
(分) & 文献 & 13 & 16 & 16 & 18 & 34 \\
\hline
\end{tabular}

から島原湾へと伸びる澪筋に沿って, 水塊は速やか に流れ込むためと考えられ，一方，下げ潮時には， 住ノ之港の周辺での水深は干潮時に1.0m以下になる ことから，流れが底面摩擦の影響を強く受けるため と考えられる. 各地点の干満差と, 口之津港を基隻 港とした時の潮時差の計算值と文献值 ${ }^{(6)}$ とを比較す ると，表一 1 のとおりである，両者には，潮時差に 最大 7 分の遅れがあるものの, 最高水位が島原湾の
中央部の港湾でほとんど同じ時刻に起こること，住 ノ江港では，それらの港湾よりも遅れて生じること が，本モデルで概ね再現されていると思われる。

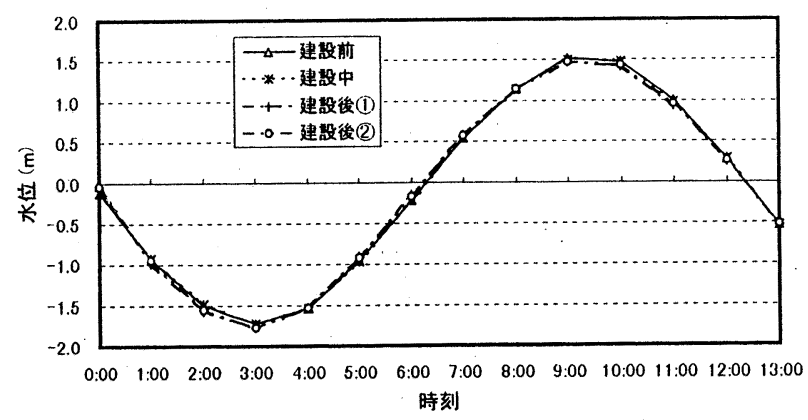

(a)St. 1 : 締切堤から湾口へ4. $0 \mathrm{~km}$

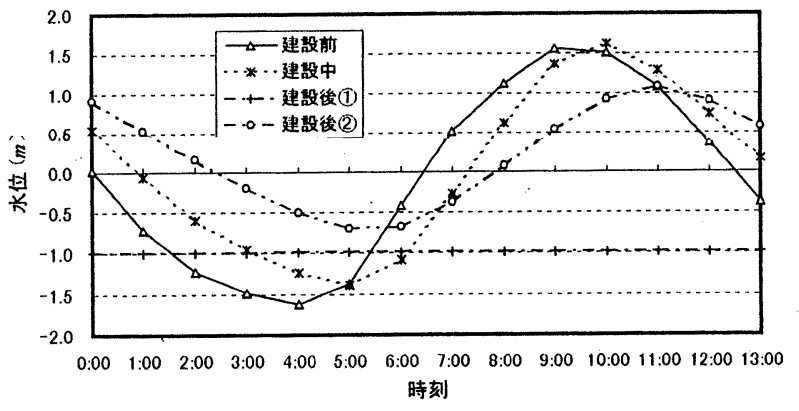

(b) St. 2 : 締切堤から湾奥へ $0.2 \mathrm{~km}$

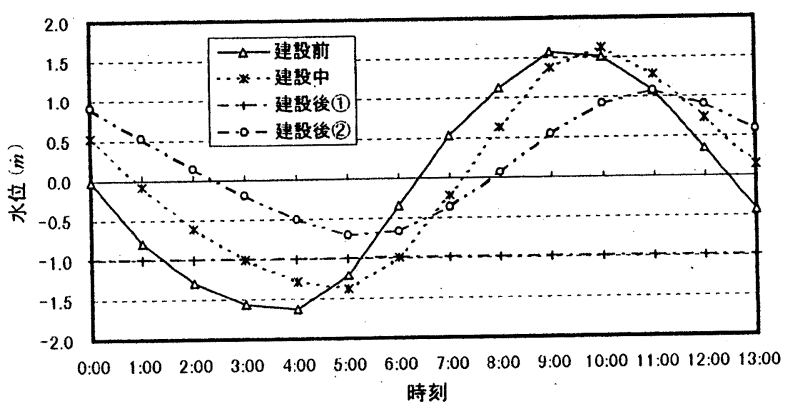

(c) St. 3 : 締切堤から湾奥へ6. $4 \mathrm{~km}$

図-4 諫早湾内での水位の時間変化 


\section{(2) 湾内の流れと干潟の変化}

流れと干潟の変化の予測は, 締切堤の建設過程を 考慮して，建設前，建設中，建設後(1)，建設後(2)の 4 つの条件で行われた. ここで，建設中の条件とし ては, 湾奥の北部の小江堤防の建設は終了し，締切 堤以潮止め区間（1,200m）が未完成の状態（1997年 1 月相当）である，とされた. 建設後(1)の条件は, 目下の計画のと抢り，締切堤の内部の水位が，北 部・南部排水門によって，-1.0mに管理された状態 とされた．建設後(2)の条件では，水門を常に開放し ている状態が想定された。底質の初期の堆積厚さに ついては，締切堤の建設に伴う変化がなる心゙く妥当 に評価されるように, 各建設条件の前段階での堆積 厚さの計算結果を初期值として与えることにした.

また，それぞれの計算では，2．で記されたように， 125時間分の助走計算がなされている.

図一4(a)〜（c）には，図一2中に示された締切 堤から湾口に向けて4.0k離れた地点 (St. 1), 締切 堤の建設地点 (St. 2), 本明川の河口部 (St. 3)におけ る水位の時間変化が示されている. 建設前での水位 変化について, 湾奥部の干潮は, 湾口部に比べて 1 時間ほど遅れるが，満潮となる時刻には大きな遅れ

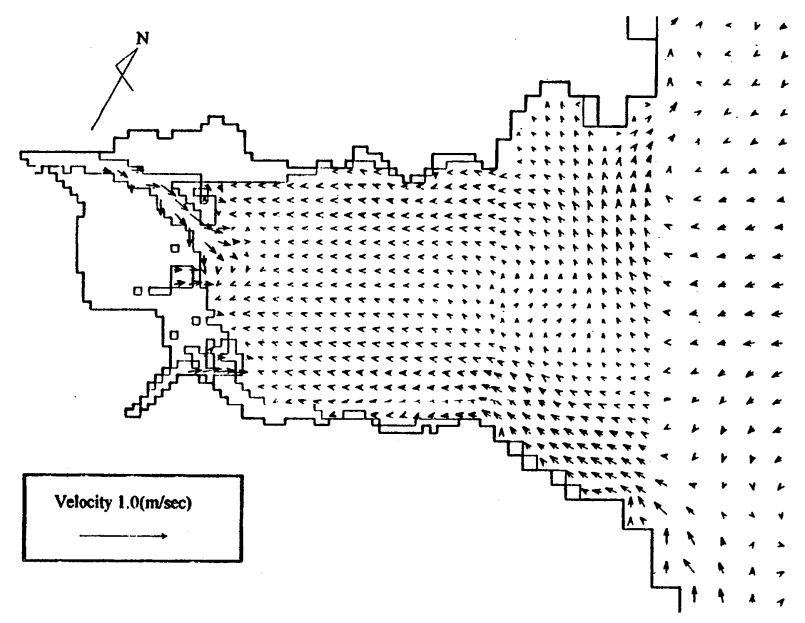

(a) 建設前

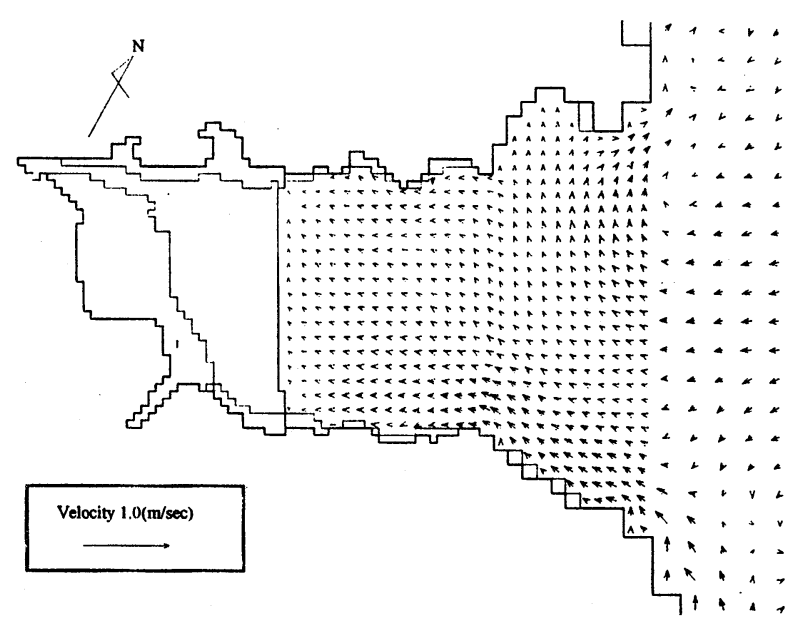

がなく, 諫早湾の水位は, 全域でほぼ同時に満潮に なるようである. 干潮時と満潮時における湾口部と 湾奥部の水位差は, それぞれ $0.14 \mathrm{~m}, 0.05 m て ゙ あ り ，$ いずれも湾奥部の水位が，湾口部より高くなってい る. 締切堤の建設が水位変化に与える影響について は, St.1での水位変化には, いずれの条件において も大きな違いは現れていない.ただし, 潮汐差は, 締切堤の建設に伴って次第に減少与る傾向にあり， 建設後(1)と建設後(2)の最高水位は，建設前に比べて 4cm低くなっている.St.2, St.3については, 建設 後(1)では, 締切堤の内側の水位が-1.0யになるよう に排水門が操作されているために， 1 潮汐間の水位 変化はほとんどない，建設中では，水位変化は，建 設前に比べて約 1 時間遅れており，干潮時の水位は， $0.23 \mathrm{~m}$ 高くなっている. 建設後(2)では，水位変化の 遅れ時間が，さらに長くなっており，St.3での満潮 時と干潮時の水位は，それぞれ0.50m低く，0.6m高 くなる. また，締切堤の湾奥側と湾口側との水位差 も大きくなっている．排水門を常に開放することが 水位変化に与える影響については，紙面の都合で水 位の空間分布が示されなかったが，排水門から湾口 方向に離れるにつれて影響は小さくなるものの，排

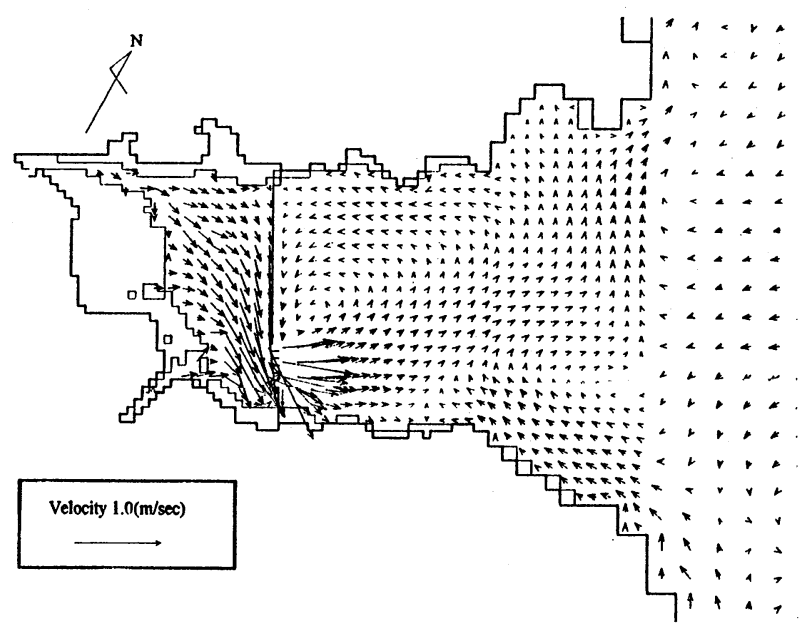

(b) 建設中

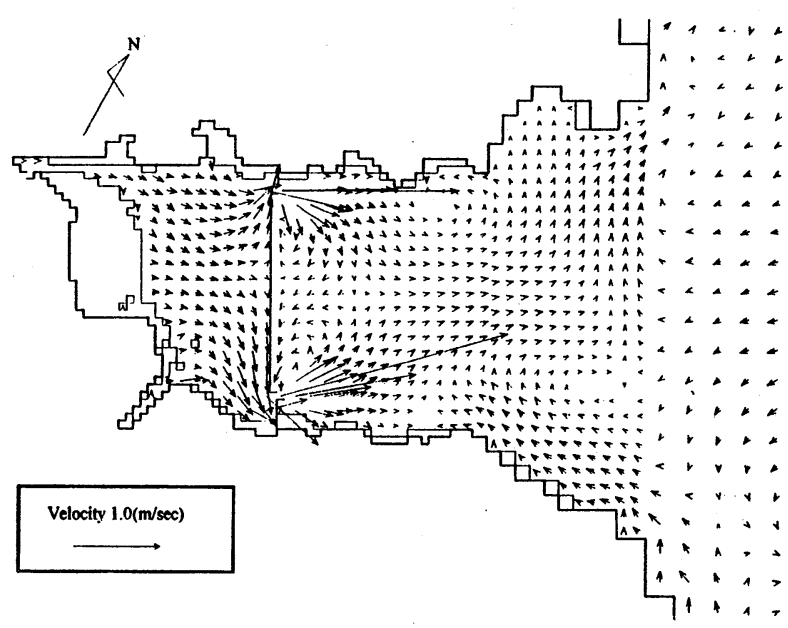

(d) 建設後(2)

(c) 建設後(1)

(干潮時) 


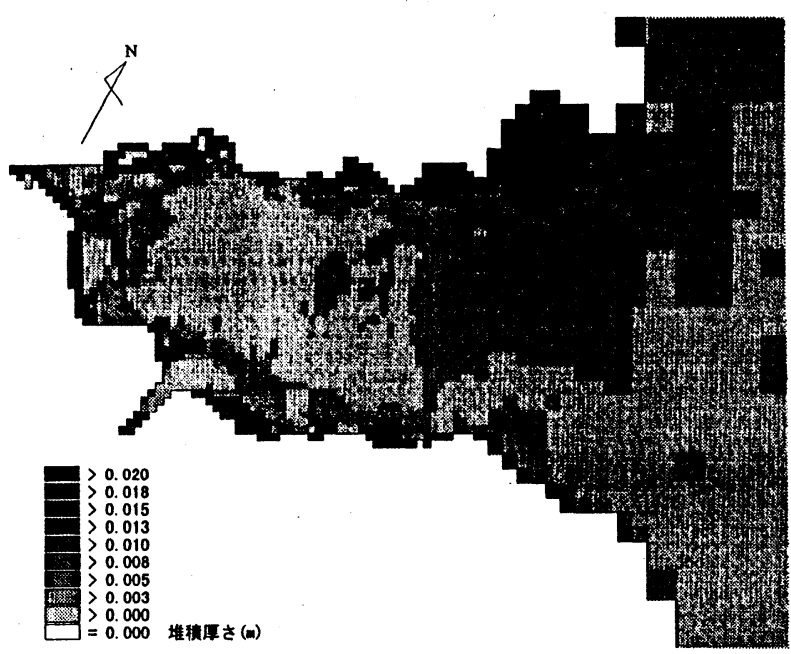

(a) 建設前

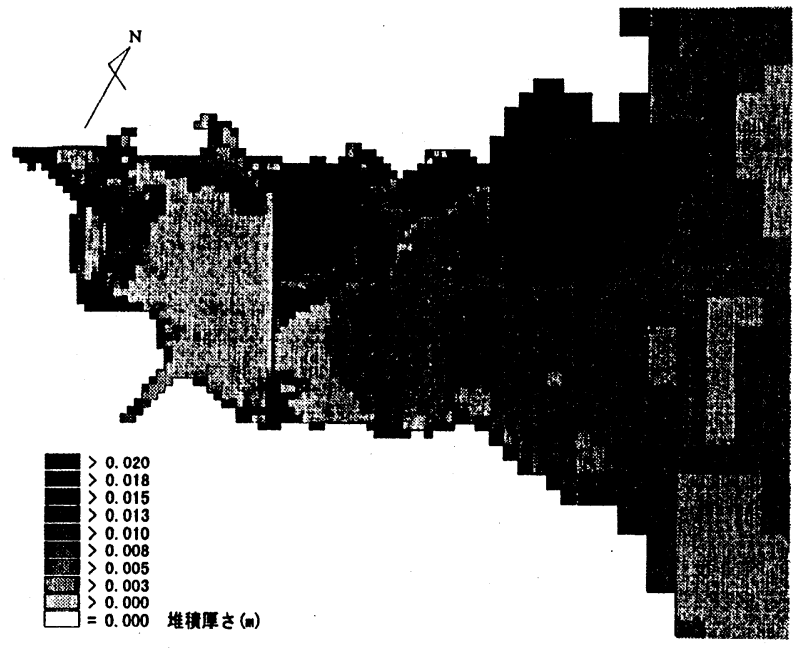

(c) 建設後(1)

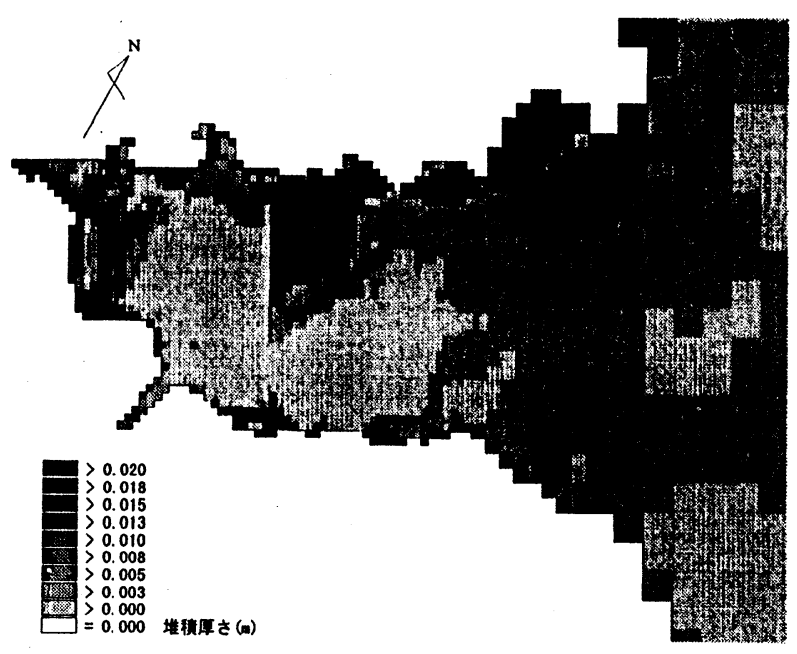

(b) 建設中

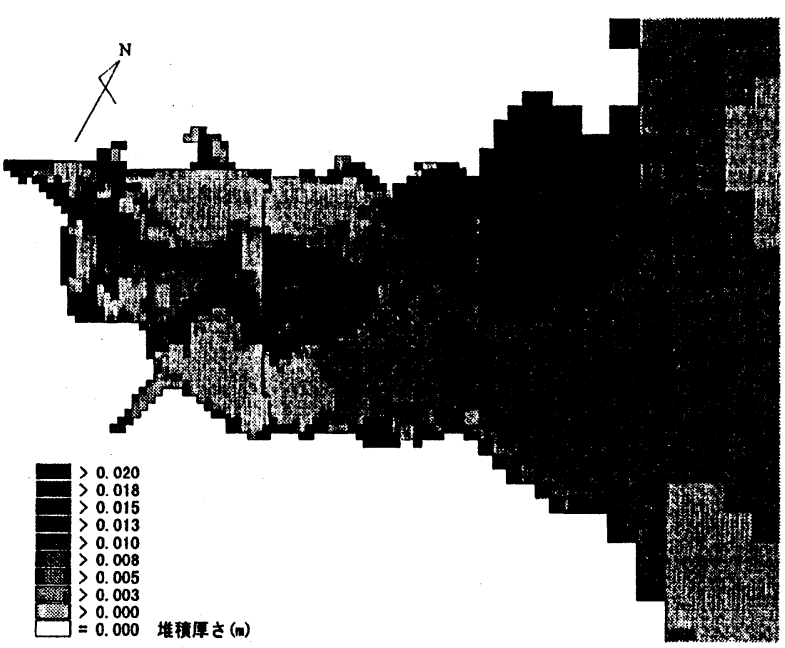

(d) 建設後(2)

図ー6 諫早湾における土粒子の堆積厚さの分布

水門から約 $1.0 \mathrm{~km}$ ま゙の範囲に達している. 建設後 (2)では，締切堤の建設によって，諫早湾の湾口から 湾奥八流入する水量が, 建設前よりも減少し, その 結果として, 湾奥部の水位に大きな変化が現れたも のと考えられる.

つぎに，計算から得られた干潮時の汀線を示せば 図一 5 (a)〜 (d) のとおりになる.ここには, 締切堤 の影響を受けたと思われる変化が生じた諫早湾と湾 口周辺部での結果のみが示されており，諫早湾の潮 汐が干潮になった時刻の結果である。この図に併記 された流速べクトルの空間分布から, 締切堤が諫早 湾の流れに与える影響は, 締切堤の建設地点を初め として, 諫早湾の湾口付近にまで達していることが 分かる.ここで, 図一 5 に示された結果から, 各条 件での諫早湾の干潟の面積を算出すると, 建設前に は, 地盤高の比較的高い湾奥部灰中心に, 北部と南 部の沿岸で25.44km²の干潟が現れているが，建設中， 建設後(1)，建設後(2)では，とれ光れ，6.84，22.32， 14. $20 \mathrm{~km}^{2}$ が減少する結果になった。減少した干潟の 面積は，建設後(1)の条件において最も大きいが，締 切堤よりも湾口側の北部と南部の沿岸では, 干潟が
現れている．建設後(2)では，図ー4で示されたよう に，湾奥部での潮汐差が小さくなるために，干潟の 面積恃建設前に比べて狭くなっており，今後，内部 堤防が建設されることを考慮すれば，湾奥では，北 岸と南岸の一部でのみ干潟が現れると予想される.

干潟の発達と消滅の要因の一つとして取り上げた 底質の堆積厚さの変化は, 図一6 (a)〜 (d) に示守と おりである.いずれの結果においても，湾口部の南 部で底質の堆積厚さの減少, 北部で増加する傾向が 見られる.このような結果になる理由は，図一5か らもとの様子がうかがえるが，上げ潮時に島原半島 沿いに島原湾から流入してきた水塊は，南部から北 部八と時計回りの緩やかな弧を描くようにして流れ ており，湾口の流速は，北部よりも南部で速いため であり，下げ潮時には，島原湾の速い流れに連行さ れるように，南部から島原湾八と流れ出るためであ る.つぎに, 諫早湾の湾奥部については, 建設前の 条件で, 沿岸域での堆積厚さが増加している。これ ら干潮時に干潟になる領域では，上げ潮時の流速が, 下げ潮時よりも速くなっており，上げ潮によって諫 早湾から流送された土粒子が堆積したものと考えら 
れる。ただし, 堆積厚さは, 干潟になる領域で一様 に増加するわけではなく, 海水が到達する前縁部に 限られるようである。一方，本明川の河口付近では， 潮の干満に伴う流れが発達するために, 土粒子は巻 き上げられ，底質の堆積厚さが減少する傾向にある。 河口域の澪筋は，こうした流れによって形成された ものと推察される. なお, 巻き上げられた底質の一 部は水底に堆積するが, 残りは海水中に懸濁態とし て存在する結果となった。建設中の条件では，締切 堤の潮止め予定区間で，上げ潮，下げ潮時の流速が 速く, 底質の堆積厚さ注少ない. しかし, 締切堤が 既に完成している場所では, 流速が減少寸るために, 流送されてきた土粒子が沈降する傾向にある. 堆積 厚さが増加寸る領域仗, 締切堤の外側に, 北部沿岸 に現れている。建設後(1)では, 島原湾からの流れが 締切堤によって遮られ, 流速汪諫早湾のほぼ全域で 遅くなっており，土粒子の堆積は，とくに諫早湾の 湾口の北部で進むようである。 また，南部において も堆積厚さが増加しており, その範囲は, 島原湾か らの流れが到達する領域に応じて分布している．湾 奥での堆積厚さの分布は, 建設中の分布とあまり変 わらない.これは, 底質の初期堆積厚さとして建設 後(1)では, 建設中の条件で算出された堆積厚さの空 間分布が与えられたこと, 締切堤よりも湾奥側の水 位が排水門の操作によってほぼ一定に保たれている ために流れがほとんどなく，土粒子があまり移動し ないことによっている. 建設後(2)では, 潮汐変化に 伴う湾内の流れは, 北部と南部排水門に集中するよ うに現れており，2つの排水門付近の流速が非常に 速くなる. そのため, 北岸と南岸の堆積厚さが著し く減少している. ただし, 締切堤の中央付近の流速 は遅く, 締切堤の湾口側では, 堆積厚さが増加する 領域が円弧状に広がっている.

現在のところ，北部・南部排水門汒，建設後(1)の ように操作されているが, 以上の結果から，十分な 土砂の供給がある場合には, 将来, 諫早湾の北部之 締切堤付近の一部で干潟が形成されることが予測さ れた。また，建設後(2)の結果に示されたように，排 水門の操作次第では, 別の場所に堆積が進むことも 併せて予測された. ただし, これらの堆積量の変化 は, 締切堤の建設の進渉による影響を直接受けて, 底泥の流送過程が変化したことで生じたものである。 堆積量の長期的な変化には, 化学的, 生物学的な懸 濁物質の生成等もまた無視できないと考えられるこ とから，諫早湾における干潟の消長を適切に予測す
るためには, 今後, 島原湾を含めた懸濁物質の移 動・生産に係る比較的長い時間スケールでの検討が 必要とされる。

\section{4. 結論}

水辺での社会基盤整備が今後も引き続き適切な形 で実施されていくためには，十分な精度で環境影響 の評価がなされておかねばならない。

本研究では，干拓事業が諫早湾に広がる干潟に及 ぼす影響について数值シミュレーションを行い，予 測結果の評価を行った。 その結果, 締切堤の建設に 伴って汀線が変化し, 締切堤の内部の干潟の面積に 大きな変化が現れることが示された．また，湾内の 流れの変化に伴って, 諫早湾の北部沿岸において, 新たに堆積の進む場所が現れることも示された。一 方で，水門の操作によっては，干潟が現れる位置や 面積が変化することも予測されている。ただし，今 回の計算で汒, 化学的, 生物学的作用による䀣濁物 の生成については考慮されておらず，また，干潟の 生成速度に関連する調整池や島原湾からの土粒子の 流送量の詳細は明らかではない. 今後, 諫早湾での 現地観測等をとおしてモデルの妥当性の検討を進め, 干潟の変化の予測精度の向上を目指したい.

謝辞 : 本研究の一部は, 平成10年度の文部省科学研 究費奨励研究 (A) (代表者: 西田渉, No. 10750391) 加 らの助成を受けて行われた。ここに記して関係各位 に深甚なる謝意を表します。

\section{参考文献}

1) Nishida, W. Noguchi, M and Mitsuhara, K: Influence Analysis of a Sea Dyke on Water Environment, Proc. Int'1 Conf on Water Resour. \& Environ. Res., VII, pp. 399-406, 1996.

2) 西田涉, 野口正人, 柳本諭: 締切堤の建設に伴う湾内の 水質変化予測, 水工学論文集, 第41巻, pp. 457-462, 1997.

3) 長崎大学教育学部教科教育学研究会編: 水際の教育と生 活科, 大日本図書, pp. 94-99, 1990.

4)栗原 康:干潟は生さている，岩波新書， 1980.

5) 村上正吾, 辻本哲郎, 中川博次 : 河床砂砅のPick-up rateの推定式について, 土木学会論文集, N0. 443, II 18, pp. 9-16, 1992.

6)海上保安庁: 平成 8 年潮汐表, 第 1 巻, 書誌第781号, 1996.

(1998. 9. 30受付) 